\title{
Bio-oil and Fuel Gas Production from Agricultural Waste via Pyrolysis: A Comparative Study of Oil Palm Empty Fruit Bunches (OPEFB) and Rice Husk
} \author{
Dani Puji Utomo' \\ ${ }^{1}$ Chemical Engineering Department, Faculty of Engineering, Diponegoro University, \\ Jl. Prof. Soedarto, S. H. Tembalang, Semarang 50275, Indonesia \\ * Corresponding author, e-mail: tdkusworo@che.undip.ac.id
}

Tutuk Djoko Kusworo ${ }^{1 *}$, Widayat Widayat ${ }^{1}$, Athaya Fairuz Mahadita', Dila Firizqina1,

Received: 17 June 2019, Accepted: 10 September 2019, Published online: 30 September 2019

\begin{abstract}
Biomass-based energy from agricultural wastes is a promising alternative energy source since its abundant supply and renewable. Biomass is converted into gas and liquid fuel through biochemical or thermochemical treatments. In this work, oil palm empty fruit bunches (OPEFB) and rice husk are pyrolyzed to produce gas and liquid fuel. The reactor temperature and feed mass are varied to obtain the best operating condition in a semi-batch pyrolysis reactor. The experimental results showed that the best operating temperature in pyrolysis process to produce bio-oils from OPEFB and rice husk was at $500{ }^{\circ} \mathrm{C}$ with $4.3 \%$ (w/w) and $2.6 \%$ (w/w) of bio-oil yields, respectively. The pyrolysis product distribution and their chemical composition are strongly affected by operating condition and the types of biomass. The GC-MS analysis results showed that the primary pyrolysis products components consist of hydrocarbons and oxygenated compounds such as carboxylic acids, phenols, ketones and aldehydes. Thermodynamic properties such as thermal conductivity of the biomass also influenced the product distribution of the biomass pyrolysis.
\end{abstract}

\section{Keywords}

agricultural wastes, empty palm fruit bunches, rice husk, bio-oil, pyrolysis

\section{Introduction}

Increasing population and industrialization in the world caused increasing energy demand globally. The world's energy demand is expected to grow by about $27 \%$, or 3.743 million tons of oil equivalents (MTOE), worldwide from 2017 to 2040 [1]. This situation is related to the availability of fossil fuels or conventional energy sources which are the main energy sources in which fossil fuels meet the needs of more than $80 \%$ of all energy sources [2]. The economic impact of fossil fuel dependency also shows by the exponential increase of fossil fuels prices along the time. The phenomena prompted many countries to develop renewable energy sources such as biomass-based energy. Many researchers study the conversion of biomass into liquid/ gaseous fuels. Since the availability of biomass source is abundant, energy recovery from it is an alternative solution to the present energy crisis.

Agricultural wastes have the potential as the source of renewable energy. They are composed of cellulose, hemicellulose, lignin, and possess high energy content [3-5].
Agricultural biomass waste is an effective solution compared to the fossil resources for industrial activities, such as power, heat and fuels for transportation. It also has high potential on the production of chemicals and biomaterials. Agricultural wastes such as oil palm empty fruit bunches (OPEFB) and rice husks are abundant in South East Asian countries such as Indonesia and Malaysia [6, 7]. Indonesia, as an agriculture country, produced 28 million tons of palm oil [8] and 70 million tons of rice annually resulted in the high rate of agricultural waste [9]. The waste becomes a social problem that has to manage immediately.

The annual productions of OPEFB and rice husk were 19 million tons and 12 million tons, respectively [10]. There are a lot of agricultural wastes conversion methods such as physical, biological, chemical, and thermal to produce a solid, liquid, and gaseous fuel. The most promising and feasible process to convert biomass into energy is the thermochemical conversion process [11]. The thermochemical conversion such as combustion, pyrolysis and 
gasification are the main thermal processes. In general, the definition of combustion is the occurrence of rapid oxidation of fuel accompanied by the production of heat and power. Complete combustion of a fuel occurs if there is sufficient oxygen supply. However, this process is not economically friendly due to the low efficiency of the combustion process and high production of emissions in particles and gas form [12]. Biomass pyrolysis is one of the most efficient technologies to produce biofuels. This process is carried out at high temperatures under an inert atmosphere which is maintained using argon or nitrogen gas. This process produces bio-oil, solid residues, and gas products. These products can be used directly or after being processed as fuel [13].

Previous researchers stated that the distribution of the bio-oil, fuel gas, and char products from pyrolysis depend on the operating condition $[14,15]$. The operating condition of fast pyrolysis is at medium temperature, which produced short vapor residence time and higher heating rate. However, the heating rate is lower than the ash pyrolysis. Ji-lu [16] performed a study on bio-oil production from rice husk using fast pyrolysis to determine the yield of bio-oil and also related properties of bio-oil. Rice husk quickly pyrolyzed at the temperature range of $420^{\circ} \mathrm{C}$ until $540{ }^{\circ} \mathrm{C}$ in a fluidized bed reactor where the main product of bio-oil obtained. The experimental result shows that increasing the pyrolysis temperature increases the bio-oil yield first and then slowly decrease. Therefore, the optimal temperature for bio-oil production from rice husks converted to bio-oil using fast pyrolysis is obtained. At the temperature of $465^{\circ} \mathrm{C}$ for rice husk, the highest bio-oil yield was $56 \%(\mathrm{w} / \mathrm{w})$. The bio-oil product was characterized using GCMS to examine its chemical compositions include heating value, stability, miscibility and corrosion characteristics. Heo et al. [17] found that the optimal fast pyrolysis temperature for the bio-oil production from furniture sawdust waste was $450^{\circ} \mathrm{C}$ with the particle size of $0.7 \mathrm{~mm}$. Increased feeding rates can reduce vapor residence times. Better results of bio-oil production obtained by maximizing the bio-oil yield at about $65 \%(w / w)$. Moreover, Park et al. [18] explain that the optimal reaction temperature for the production of biooil was $450^{\circ} \mathrm{C}$. The increase of flow rate and feeding rate can increase the bio-oil yields gradually; however, these did not significantly affect the yields of bio-oil. Sulaiman and Abdullah [19] researched fast pyrolysis using empty palm fruit bunches, which give the highest bio-oil yield at $55 \%$ depending on the particle size of ash content at a reactor temperature of $450{ }^{\circ} \mathrm{C}$. The process with short reaction time (only a few seconds) known as flash pyrolysis is using a higher heating rate. Hence a small particles size is required. Slow pyrolysis is a thermal cracking process that occurs at lower process temperature and lowers heating rate. Due to the lower heating rate, the vapor residence times are longer. Guedes et al. [20] conducted pyrolysis of rice husk at the temperature of $450{ }^{\circ} \mathrm{C}$ and produced the highest yield of $70 \%(\mathrm{w} / \mathrm{w})$ bio-oil in liquid form. The change of pyrolysis temperature caused many results in yield. The previous study also explained about the pyrolysis of oil palm empty fruit bunches in a benchscale of fluidized bed reactor, which obtained the highest bio-oil yield of $55 \%(\mathrm{w} / \mathrm{w})$. Depending on the particle size of ash content, the vapor residence time used at the temperature of $450^{\circ} \mathrm{C}$ is about $1.03 \mathrm{~s}$ [19].

Conventionally, fast pyrolysis is commonly used if the desired end product is the liquid hydrocarbon. The biooil product provides significant advantages in storage and transportation, but fast pyrolysis required very high temperature so that the materials needed for the equipment must be resistant by high temperature. However, the operating conditions of slow pyrolysis process can be varied to produce large amounts of bio-oil and gas other than char. Based on the previous research, bio-oil production still have some shortcoming. Therefore, in this research rice husk and OPEFB biomass were pyrolyzed in a batch reactor to obtain bio-oil with a higher yield. In particular, the specific objectives of this research are to examine the influence of different feed mass and temperature of OPEFB and rice husk as feed. The bio-oil and gas product compositions from OPEFB and rice husk were analyzed and compared.

\section{Materials and methods}

\subsection{Materials}

Rice husk obtained from local paddy farms in Semarang, Indonesia. The empty palm fruit bunches (OPEFB) obtained from palm farms in North Sumatra, Indonesia. The samples were collected and then dried using a dry, hot air oven at $100 \pm 5^{\circ} \mathrm{C}$ for $24 \mathrm{~h}$ to remove the moisture. The dried biomass samples were ground and then sieved using 100 mesh vibrator sieves. The biomass powders were characterized and used as feedstocks in the pyrolysis reactor. The Industrial grade nitrogen gas with a purity of $99.9 \%$ purchased from Aneka Gas, Ltd., Indonesia. 


\subsection{Proximate and ultimate analysis of rice husk and OPEFB}

The Ultimate analysis was carried out using an ASTM D 5373-16 standard method to determine the elemental composition of biomass such as carbon, hydrogen, nitrogen, and sulfur [21]. The proximate analysis was performed using method ASTM D 3173-17 for moisture analysis [22], ASTM D 3174-12 for ash content [23], ISO 562-2010 for volatile matter [24], ASTM D 3172-13 for fixed carbon [25] and ASTM D 5865-13 for gross heating value [26].

\subsection{Biomass pyrolysis experimental procedure}

The pyrolysis experiments were performed using a benchscale semi-batch pyrolysis reactor, as shown in Fig. 1. The reactor is a vertical cylinder stainless-steel vessel with a height of $30 \mathrm{~cm}$ and an internal diameter of $10 \mathrm{~cm}$. The reactor was electrically heated using a coil heater of 1.5 $\mathrm{kW} 3$ phase AC. To control the temperature, the reactor equipped with thermocouple connected to a PID controller monitor. The reactor was insulated using asbestos insulator to prevent heat loss and the hot reactor surface. The reactor connected to an insulated stainless-steel pipe at the top of the reactor that also connected with a double series of the shell-and-tube condenser. The bio-oil product can be obtained from each condenser outlet periodically. The uncondensed gas was trapped using a gas bag at another outlet of the condenser.

These experimental procedures were conducted in two main stages: thermally pyrolysis reaction and separation process [27]. The first stage of bio-oil production from rice husk and OPEFB by feeding the biomass powder (rice husk/OPEFB) into the reactor with varied mass feed (150; $250 ; 350 ; 450 \mathrm{~g})$ to acquire the optimum feed mass, followed by set the reactor temperature condenser at varied

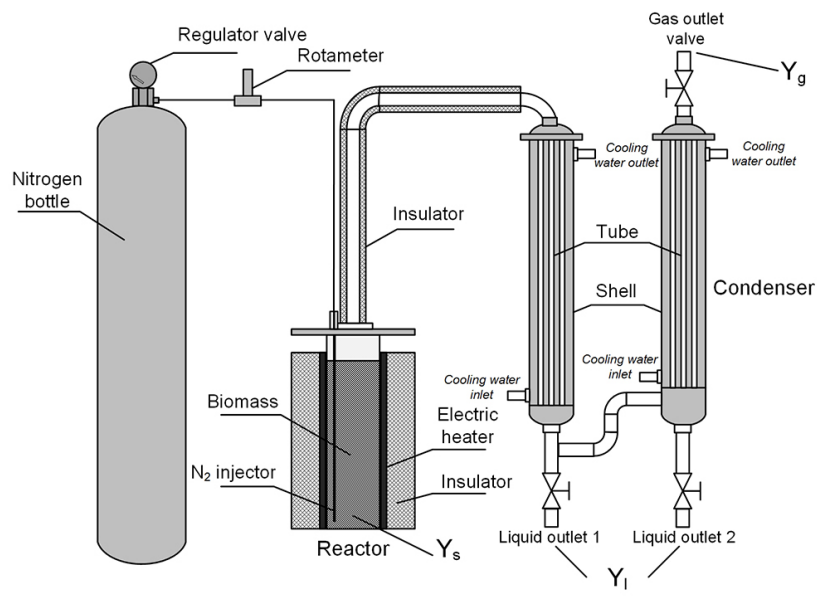

Fig. 1 Pyrolysis reactor equipment set temperature $\left(300 ; 400 ; 500 ; 600^{\circ} \mathrm{C}\right)$ in order to attain the highest bio-oil yield produced. Nitrogen gas was streamed to the reactor at $1.5 \mathrm{~mL} / \mathrm{min}$ to eliminate the oxygen inside the reactor to prevent combustion reaction. The pyrolysis process produced two main products, liquid and gas products. The total liquid consists of water and pyrolysis oil (bio-oil) that separated via gravity settling. The gas product was collected and analyzed to determine its chemical composition. The solid residue of bio-char was collected after the process was shut down and the reactor reached room temperature. After that, the final mass was measured.

The yield of bio-oil, char and also gas produced by each experimental run were calculated using Eq. (1)-(4) [28].

$$
\begin{aligned}
& Y_{L}, w t-\%=\frac{w_{i}}{w_{f}} \times 100 \% \\
& Y_{o}, w t-\%=\frac{w_{o}}{w_{f}} \times 100 \% \\
& Y_{s}, w t-\%=\frac{w_{s}}{w_{f}} \times 100 \% \\
& Y_{g}, w t-\%=100 \%-\left(Y_{L}+Y_{s}\right)
\end{aligned}
$$

Where, $Y_{L}, Y_{o}, Y_{s}$, and $Y_{g}$ are liquid yield, oil yield, char yield, and gas yield, respectively. $w_{i}=$ mass of total liquid product, $w_{o}=$ mass of separated bio-oil, $w_{s}=$ mass of solid residue, and $w_{f}=$ mass of the biomass feed.

\subsection{Bio-oil and gas products characterization using GCMS}

Analysis of GCMS or Gas Chromatography Mass Spectrometry is performed to ensure that structural changes have occurred in the oil, and to know the various types of compounds contained in the pyrolysis product sample specifically, in the presence of this analysis can be known percentage for each type of compound contained in pyrolysis products.

\section{Results and discussions}

\subsection{Characterization of rice husk and OPEFB}

Ultimate and proximate analysis of rice husk and OPEFB are essentials for potential energy estimation in biomass. The results of the ultimate and proximate characterization showed in Table 1. The moisture content of rice husk is higher than OPEFB. The hygroscopic behavior of rice husk is related to the high content of silica [29]. The ash content of rice husk is also much higher than OPEFB, where some reports showed that rice husk substantially 
Table 1 Proximate and ultimate analysis of OPEFB and rice husk

\begin{tabular}{lccc}
\hline \multirow{2}{*}{ Parameter } & Unit & \multicolumn{2}{c}{ Value } \\
\cline { 3 - 4 } & & OPEFB & Rice Husk \\
\hline Proximate analysis & $\%$ & 9.2 & 12.7 \\
Moisture & $\%$ & 10.6 & 16.1 \\
Ash content & $\%$ & 61 & 55.5 \\
Volatile matter & $\%$ & 19.2 & 15.7 \\
Fixed carbon & $\mathrm{kcal} / \mathrm{kg}$ & 4010 & 3627 \\
Gross Heating Value & & & \\
(GHV) & $\%$ & 42.32 & 45.2 \\
Ultimate analysis & $\%$ & 5.74 & 5.8 \\
Carbon (C) & $\%$ & 1.84 & 1.02 \\
Hydrogen (H) & $\%$ & 39.24 & 47.6 \\
Nitrogen (N) & $\%$ & 0.26 & 0.21 \\
Oxygen (O) & $\%$ & & \\
Sulfur & $\%$ & & \\
\hline
\end{tabular}

* $\mathrm{H}$ and $\mathrm{O}$ reported include moisture

had ash content higher than $15 \%$ and the major component is silica compound. Higher ash content may reduce the heating value estimation of the biomass however it is beneficial from another perspective that higher ash content present in agricultural biomass waste has potential to be used in brick manufacture, catalyst production, silica recovery, etc. $[30,31]$. The lower volatile matter was found in the rice husk i.e. $55.5 \%$. From this information, it could be estimated that overall rice husk has a lower conversion for the pyrolysis process compared with OPEFB.

From the elemental composition review, sulfur was found to be slightly higher in OPEFB than rice husk indicates that rice husk was potentially more ecofriendly. The heating value of the samples is reported in Table 1. The gross heating values were determined using bomb calorimeter. The GHV of OPEFB is higher than rice husk. The phenomena were following the results of the proximate characterization that rice husks contain less volatile material than OPEFB. The GHV of agricultural wastes (rice husk and OPEFB) showed that this biomass has potential as a renewable energy resource that able to convert to usable bio-energy products.

\subsection{Effect of the OPEFB feed mass on product yield}

The effect of the OPEFB mass on bio-oil, char and gas yield discusses in this subchapter by varying the mass of feed. The pyrolysis of OPEFB was carried out at $600{ }^{\circ} \mathrm{C}$ with biomass mass of $150,250,350$, and $450 \mathrm{~g}$. The pyrolysis product yields with varying biomass mass at $600{ }^{\circ} \mathrm{C}$ are shown in Fig. 2.

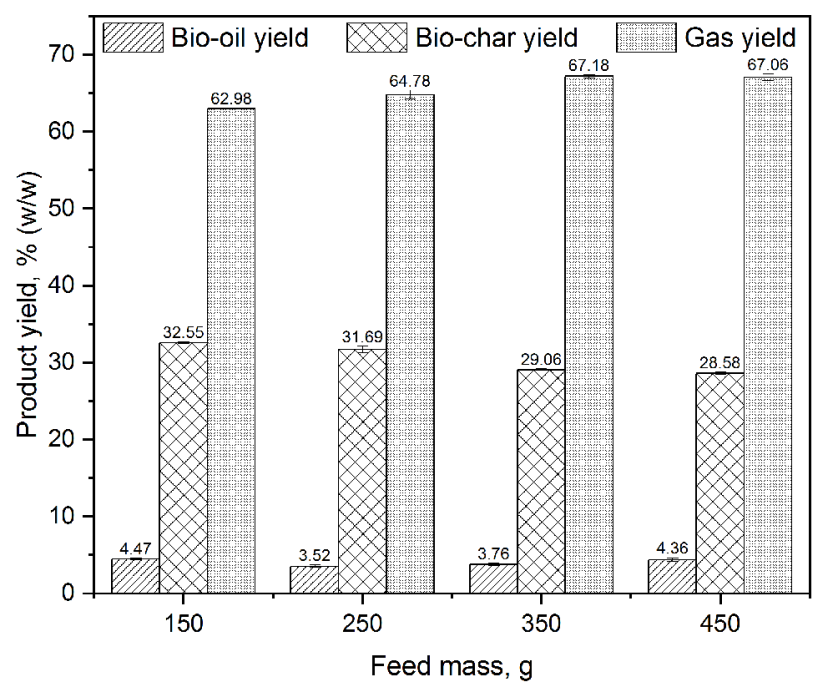

Fig. 2 OPEFB pyrolysis product yields with varied feed mass at $600^{\circ} \mathrm{C}$

Fig. 2 shows that the correlation between biomass mass on product yields. The solid phase (char) and liquid phase (bio-oil) product fraction determined by measuring the solid and liquid product's mass directly. The gas phase is obtained by subtracting total mass with the mass of liquid and solid products. At the higher biomass mass of $450 \mathrm{~g}$, the char yield reached $29.3 \%$. The increasing of OPEFB mass at the range from 150 to $450 \mathrm{~g}$, the bio-oil yield increased from $3.9 \%$ to $4.7 \%$. The gas yield increased from 60 to $64 \%$ along with the increase of OPEFB feed mass.

Cellulosic biomass can be converted into bio-oil through pyrolysis process as reported by the previous study, the production of bio-oil increased up to $62-72 \%$ (w/w) at higher rate. While, the char production decreased when the tar formation increased [32]. OPEFB contains cellulose, hemicellulose and lignin. Cellulose content in OPEFB was reported in the range of $37.3-46.5 \%$, hemicellulose content are 25.3-33.8\% and lignin content are 27.6-32.5\% [33]. OPEFB potentially can be converted into bio-oil via pyrolysis. As shown in Fig. 2, at feed mass of $450 \mathrm{~g}$, the highest bio-oil yield was obtained, it was $4.7 \%$ and the lowest char yield was obtained up to $29.3 \%$. The large gap between the bio-oil result in this study and previous study might be due to the condensing system, where condensable gasses escaped the condensing system in this study. The higher biomass mass at this range produce higher liquid yield (bio-oil). However, if the feed mass is high enough, the products yield may decrease because the heater cannot accommodate the energy for cracking process and at constant heating power the heating rate become lower with higher feed mass. 
At lower OPEFB mass gives faster heat transfer, which led to faster devolatilization, and the formation of organic vapor and gas [34]. The lower OPEFB feed mass in batch reactor provides a longer residence time of volatile compounds in the reactor vessel, which lead on the secondary cracking of organic vapor into an incondensable gas product. Besides, a longer residence time provides the possibility of a re-polymerization process that produces secondary charcoal. In the other side, shorter vapor residence time was affected by the increasing of OPEFB feed where the secondary cracking and a re-polymerization process are not preferred, so the gas and charcoal yields are low. The previous study also showed that at higher biomass feed mass increased the liquid product of pyrolysis process significantly [20].

\subsection{Effect of the pyrolysis temperature on products yield in OPEFB pyrolysis}

The effects of the reactor temperature of OPEFB pyrolysis on the yield of the products were studied by varying the temperature reactor from $300{ }^{\circ} \mathrm{C}$ to $600{ }^{\circ} \mathrm{C}$ at constant OPEFB feed mass of $450 \mathrm{~g}$. The profile of pyrolysis products yield with varied pyrolysis temperature are shown in Fig. 3.

Fig. 3 shows that at the lowest pyrolysis temperature of $300{ }^{\circ} \mathrm{C}$, decomposition is not significant because the yield of solid material is the primary product. It indicates that biomass is not converted at this range of temperature. The bio-oil yield reached the highest value of $5 \%(\mathrm{w} / \mathrm{w})$ at $500{ }^{\circ} \mathrm{C}$ operating temperature. At higher pyrolysis temperatures of $600{ }^{\circ} \mathrm{C}$, the bio-oil yield decreased to $4.7 \%$ (w/w). The gas yield obtained at the range of $15-60.4 \%(\mathrm{w} / \mathrm{w})$ over the temperature range of $300{ }^{\circ} \mathrm{C}$ to $600{ }^{\circ} \mathrm{C}$. The operation at $300{ }^{\circ} \mathrm{C}$ shows the lowest yield and the highest yield obtained at a temperature of $600{ }^{\circ} \mathrm{C}$. The high gas yield at higher temperature was the result of the pyrolysis vapors conversion into non-condensable gases through secondary cracking at the higher reaction temperature. The volatiles evolved from pyrolysis were introduced into the next zone for the secondary reactions. The secondary cracking usually occurs at a temperature range of $600-900{ }^{\circ} \mathrm{C}$ [35]. This trend of bio-oil production affected by temperature was in agreement with the previous research [36].

Based on Fig. 3, the increase of temperature significantly enhanced the bio-oil yield until a specific value, the addition of temperatures over the maximum values gave the opposite result. At high temperature (over than $500{ }^{\circ} \mathrm{C}$ ) there is a secondary cracking of the volatiles compounds which produce higher gas yields. Fig. 3 shows

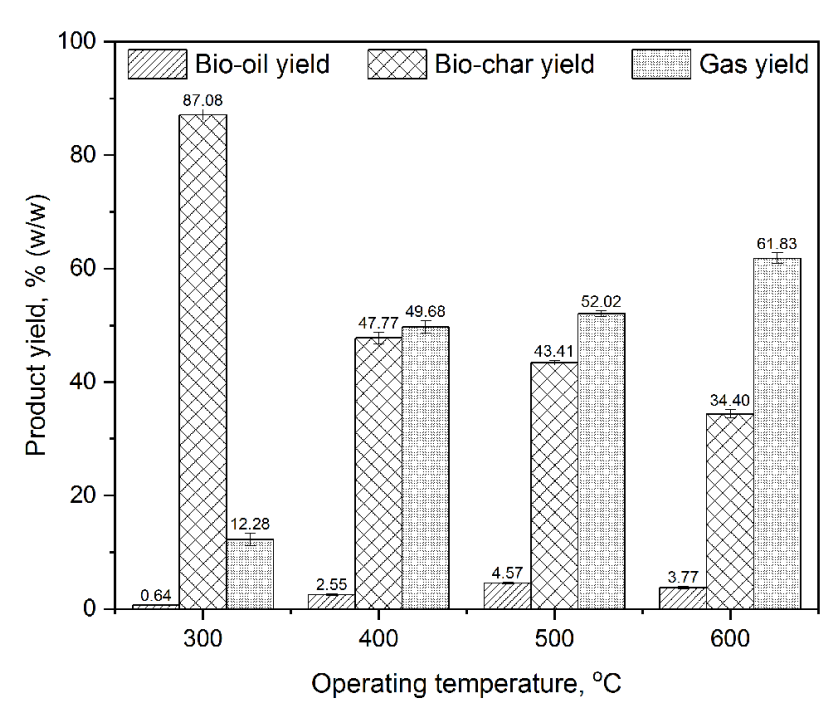

Fig. 3 OPEFB pyrolysis product yields with varied reactor temperature

that by increasing the temperature from $300{ }^{\circ} \mathrm{C}$ to $500{ }^{\circ} \mathrm{C}$ enhanced the bio-oil yield from $0.8 \%-5 \%$. While the increase of temperature from 500 to $600{ }^{\circ} \mathrm{C}$ reduce the bio-oil yield to $4.7 \%$.

The yield of biochar in OPEFB pyrolysis decreased drastically from $84 \%$ to $35 \%$ when the temperature changed from $300{ }^{\circ} \mathrm{C}$ to $600{ }^{\circ} \mathrm{C}$. Char is the solid residue of the biomass pyrolysis that consists of mineral ash, heavy organics and carbon, its elemental composition and structure vary with the pyrolysis temperature. Also, the char loses hydrogen and oxygen as temperature rises. On a high-temperature condition, the addition of liquid and gas components released from OPEFB pyrolysis results to the high carbon residue character. The increase in temperature leads to a decrease in the char yield [37].

The gas yield increases at a higher temperature with the highest gas yield up to $60 \%(\mathrm{w} / \mathrm{w})$ at the pyrolysis temperature of $600{ }^{\circ} \mathrm{C}$. The enhancement of gas yield was related to the secondary cracking of the organics vapor and secondary decomposition of the char at a higher temperature. It indicates that the increase in pyrolysis temperature followed by the increase of gas yield [38].

\subsection{Effect of the rice husk feed mass on pyrolysis products yield}

The effects of the rice husk feed mass on the yield of biooil, bio-char and gas were investigated by varying the feed mass ranging from 150 to $450 \mathrm{~g}$ at a constant temperature of $600{ }^{\circ} \mathrm{C}$. The profiles of pyrolysis products yield as the effects of various rice husk mass showed in Fig. 4.

Fig. 4 shows the product distribution of rice husk pyrolysis at various feed mass. The bio-char product slightly 


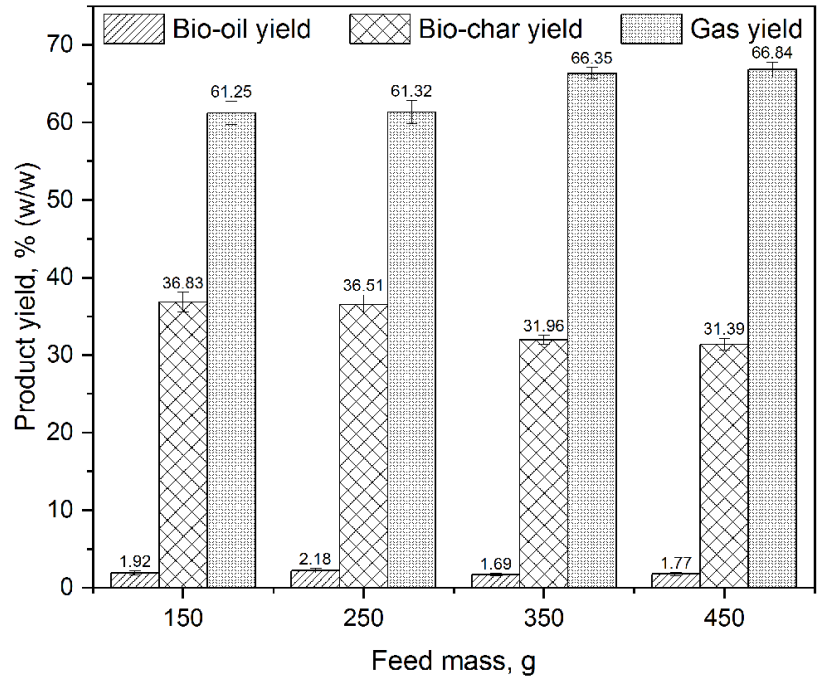

Fig. 4 Rice husk pyrolysis products yield with varied feed mass at $600{ }^{\circ} \mathrm{C}$

decreases with the increase of rice husk feed mass. The lowest bio-char product was achieved at $450 \mathrm{~g}$ of rice husk mass i.e $31.6 \%$. The increasing of rice husk feed mass at the range of 150 to $450 \mathrm{~g}$, the bio-oil yield increased from 3.7 to $4.1 \%(\mathrm{w} / \mathrm{w})$ as well as the gas yield increased from 59.7 to $64.2 \%(\mathrm{w} / \mathrm{w})$.

Pyrolysis products distribution of rice husk is similar to OPEFB pyrolysis products distribution. In general, the higher feeding mass may lead to preventing secondary cracking of organic volatiles due to short residence time, which results in higher bio-oil yield. Compared with OPEFB pyrolysis products distribution, rice husk pyrolysis produced the less bio-oil product. This behavior depends on biomass constituent compounds, the cellulose, hemicellulose, and lignin structures in rice husk are more degradable than OPEFB. Furthermore, the bio-char production from rice husk is higher than average char production of OPEFB pyrolysis, due to the higher mineral content of rice husk, as shown in biomass characterization results (Table 1).

Rice husks contained cellulose, hemicellulose, lignin and extractives. The cellulose content on rice husks is $25-35 \%(\mathrm{w} / \mathrm{w})$, the hemicellulose content is $18-21 \%$ (w/w), while lignin and minerals contents are 26-31\% $(\mathrm{w} / \mathrm{w})$ and $15-17 \%(\mathrm{w} / \mathrm{w})$, respectively [39]. OPEFB contained $24-65 \%(\mathrm{w} / \mathrm{w})$ of cellulose, 21-34\% (w/w) of hemicellulose, and $14-31 \%(\mathrm{w} / \mathrm{w})$ of lignin [40]. The lignocellulosic compounds are the main constituent which potentially converted into usable energy products. Since the lignocellulosic content of rice husk is lower than OPEFB's thus in the potential conversion of rice husk is expected to be lower than OPEFB's as revealed in this study. Thus the OPEFB is more potential to be utilized as biomass feedstock in bio-energy production besides its abundant availability.

\subsection{The effects of operating temperature on the yield of rice husk pyrolysis products}

The effects of the pyrolysis temperature of rice husk on yield of bio-oil, char and gas were studied by varying the temperature of pyrolysis reactor $(300,400,500$, and $600{ }^{\circ} \mathrm{C}$ ) using rice husk as biomass feedstock and the feed mass was fixed at $450 \mathrm{~g}$ (the best condition from varied mass experiments). The products distribution with reactor temperature variation are shown in Fig. 5.

The distribution of product yield of rice husk pyrolysis at various operating temperature has similarities with OPEFB, it indicates that lignocellulosic biomass has similar pyrolysis product distribution. The pyrolysis process at $300{ }^{\circ} \mathrm{C}$ (lowest temperature in this study) shows a solid product as the primary product, up to $83 \%(\mathrm{w} / \mathrm{w})$, because the decomposition process at $300{ }^{\circ} \mathrm{C}$ is insignificant. The highest bio-oil production of $2.58 \%(\mathrm{w} / \mathrm{w})$ obtained at $500{ }^{\circ} \mathrm{C}$. However, this level is much lower than the bio-oil production from OPEFB. The highest gas yield obtained at the temperature of $600{ }^{\circ} \mathrm{C}$. In general, temperatures influence the distribution of the pyrolysis product. At low temperature $\left(300-400{ }^{\circ} \mathrm{C}\right)$ bio-char yield reaches the highest level, at medium temperature $\left(500{ }^{\circ} \mathrm{C}\right)$ bio-oil yield reaches the highest level, and at high temperature $\left(>600{ }^{\circ} \mathrm{C}\right.$ ) gas yield achieves the highest level due to secondary cracking of organic volatile which indicated by the decreasing of bio-oil yield.

Higher temperatures caused more char cracks which produce more gas products and lower charcoal yields.

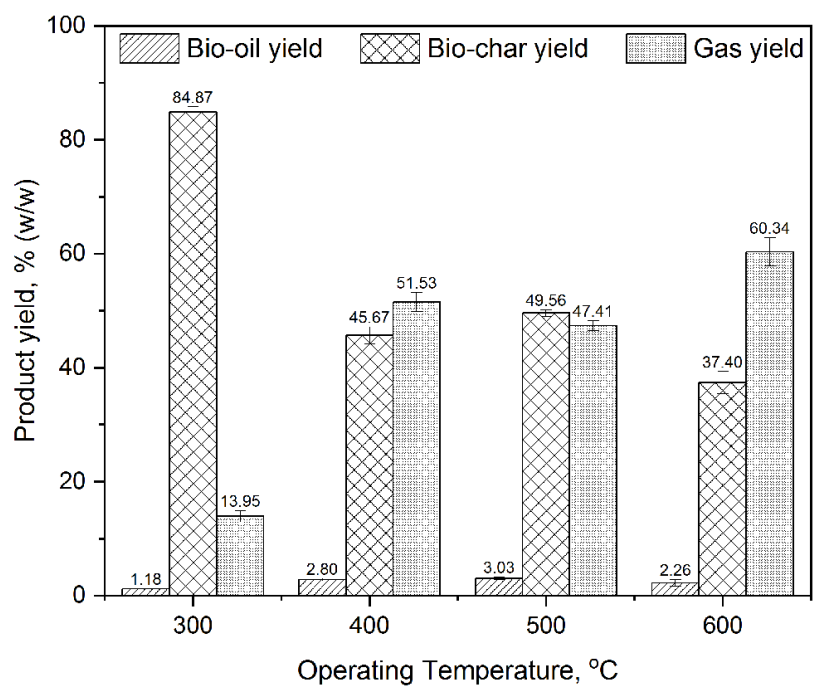

Fig. 5 Rice husk pyrolysis products yield at various operating temperature 
When the pyrolysis temperature increases, the charcoal yield decreases. At high temperatures, the primary pyrolysis rate and the thermal cracking rate of char becomes gas product is high [41].

Some critical point obtained from this experimental study is, (1) bio-oil yields increases at medium operating temperature and then decreases with temperature increase; (2) non-condensable gas yields relatively increase varying with temperature, the highest level achieved at temperature of $600{ }^{\circ} \mathrm{C}$ with yield of $59 \%$; and (3) the rise of temperature significantly decreases the biochar yield. The result of this study is following a previous research report [42] that the higher operating temperature leads to the secondary cracking of organic vapor, resulting in higher gas yield and lower bio-oil yield. In general, pyrolysis conversion of solid biomass increases along with the increase of temperature. The charcoal yield decreased by the temperature rise due to a more significant primary decomposition of rice husks at higher temperatures or a secondary decomposition of char residues. Secondary decomposition of charcoal at higher temperatures can also provide non-condensable

Fig. 6 and 7 show the chromatogram of chemical composition of the bio-oil obtained from OPEFB and rice husk pyrolysis, respectively. For the detail information regarding to chemical composition of OPEFB bio-oil product are shown in Table 2. Aromatics and oxygenated compounds such as carboxylic acids, phenols, ketones and aldehydes are the primary compounds found in bio-oil. The portion of hydrocarbon derivatives is $43.01 \%$, and oxygenated hydrocarbon (esters are the major components) is $56.99 \%$. The presence of aromatic and oxygenated compounds is associated with the chemical structure of the biopolymers such as cellulose, hemicellulose, lignin and extractive components. The esters products may come from the degradation of triglycerides esters that contained in OPEFB at a relatively high level [43].

OPEFB is lignocellulosic biomass due to its high cellulose content. OPEFB has the potential to be converted as a promising alternative to fuel as well as bio-oil production.
Table 2 Chemical composition of bio-oil from OPEFB pyrolysis according to the GC-MS analysis

\begin{tabular}{|c|c|c|}
\hline No. & Compound name & Mole fraction $(\%)$ \\
\hline 1 & Phenol & 9.23 \\
\hline 2 & Pentadecane & 1.87 \\
\hline 3 & Dodecanoic acid, methyl ester & 4.27 \\
\hline 4 & Hexadecane & 2.12 \\
\hline 5 & Nonadecane & 2.54 \\
\hline 6 & Tetradecanoic acid, methyl ester & 1.91 \\
\hline 7 & Pentadecane, 2,6,10,14-tetramethyl- & 3.90 \\
\hline 8 & Octadecane & 2.41 \\
\hline 9 & Nonadecane & 2.28 \\
\hline 10 & Hexadecanoic acid, methyl ester & 3.92 \\
\hline 11 & Octadecane & 2.13 \\
\hline 12 & 9-Octadecenoic acid-, methyl ester & 3.68 \\
\hline 13 & Pentratriacontane & 1.97 \\
\hline 14 & Tetratetracontane & 1.78 \\
\hline 15 & Tetratetracontane & 2.00 \\
\hline 16 & Tetratetracontane & 1.88 \\
\hline 17 & Nonacosane & 2.78 \\
\hline 18 & Glyceryl tridecanoat & 4.50 \\
\hline 19 & Dodecanoic acid, 1,2,3-propanetriyl ester & 2.55 \\
\hline 20 & $\begin{array}{l}\text { 7-Methoxy-2,6,6-trimethyl-6,7-dihydro- } \\
\text { 5H-oxepin-4-one }\end{array}$ & 1.91 \\
\hline 21 & $\begin{array}{l}\text { Eicosanoic acis, 2,2-dimethyl-1,3- } \\
\text { dioxolan-4-ylmethyl ester }\end{array}$ & 2.32 \\
\hline 22 & Octadecanoic acid, butyl ester & 2.38 \\
\hline 23 & 2-Lauro-1,3-Didecoin & 7.41 \\
\hline 24 & Dodecanoic acid, 1,2,3-propanetriyl ester & 3.53 \\
\hline 25 & $\begin{array}{l}\text { Octadecanoic acid, 2,3-bis[(1- } \\
\text { oxotetradecyl)oxy]propyl ester }\end{array}$ & 4.38 \\
\hline 26 & Nonadecane & 5.70 \\
\hline 27 & 2-(3'-hydroxybutyl)cyclooctanone & 3.80 \\
\hline 28 & $\begin{array}{l}\text { Eicosanoic acid, 2,2-dimethyl-1,3- } \\
\text { dioxolan-4-ylmethyl ester }\end{array}$ & 2.63 \\
\hline 29 & Gliceryl tridecanoat & 5.98 \\
\hline 30 & Docosane & 2.24 \\
\hline
\end{tabular}

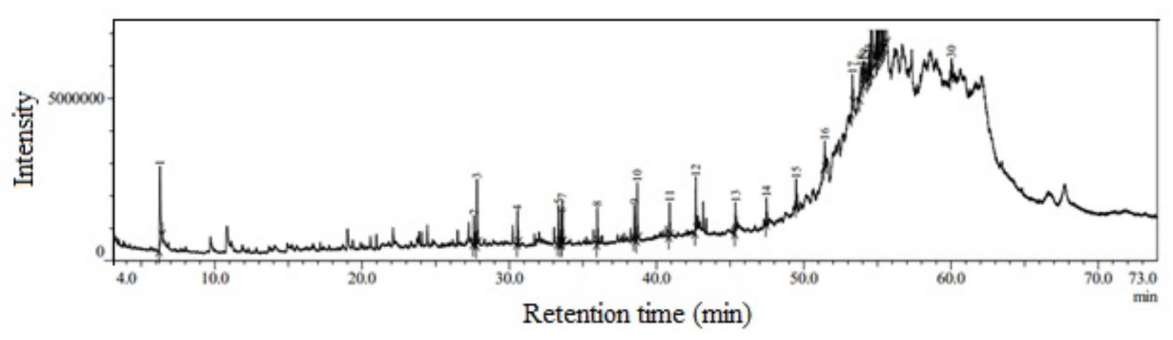

Fig. 6 Chromatogram of bio-oil from OPEFB pyrolysis 


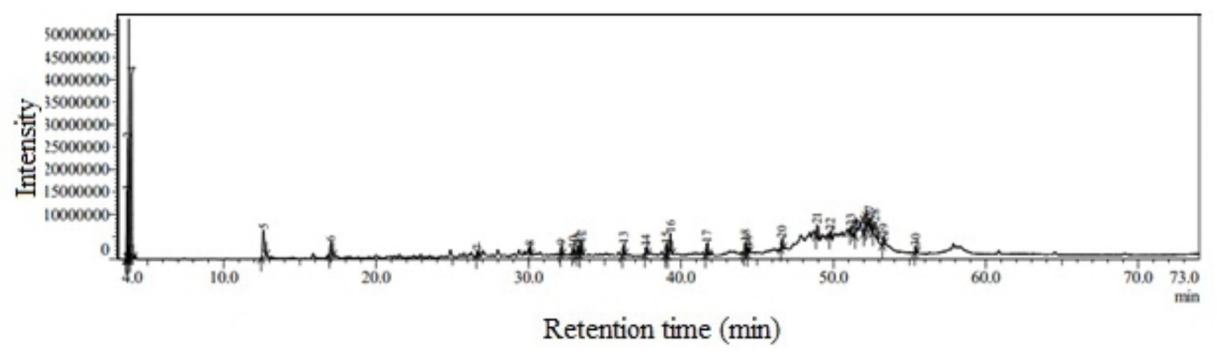

Fig. 7 Chromatogram of bio-oil from rice husk pyrolysis

Table 3 shows the GC-MS result for the bio-oil pyrolysis product of rice husk, which reveals that the portion of hydrocarbon derivatives and oxygenated hydrocarbon (phenols) are $88.19 \%$ and $11.81 \%$, respectively. The amount of oxygenated hydrocarbon compounds in rice husk bio-oil is much lower than that in OPEFB due to the lower lignin content in rice husk. Lignin and extractive components are the sources of oxygenated hydrocarbon products. As reported by previous research, the thermal decomposition of lignin in the absence of air may produce monophenols, monolignols, alcohols, ketones, and aldehydes [44].

The number of the cellulosic compound contained in OPEFB is higher than rice husks. High cellulose content produced a water-rich liquid phase along with small portions of propionaldehyde, butanedione, butyraldehyde, furan, acrolein, acetaldehyde, crotonaldehyde, acetone and methanol. There are two types of cellulose degradation, gradual degradation, decomposition and combustion on heating at low temperatures, and rapid volatilization accompanied by levoglucosan formation on pyrolysis at higher temperatures. After pyrolysis, the residue was found to consist of several water-soluble materials, in addition to charcoal and cellulose which not decomposed. Aromatics, phenols and alkyl substituted fractions are formed by recombination and cyclization reactions, through condensation of Aldol, from fragments $\mathrm{C}_{2}, \mathrm{C}_{3}$ and $\mathrm{C}_{4}$ which are initial degradation products. Further reactions can produce furan, aldehydes and ketones.

The distribution of hydrocarbon on bio-oil from empty palm oil bunches and rice husks is shown in Fig. 8. Based on Fig. 8, the number of alkanes on bio-oil of empty palm oil bunches is higher than rice husks, but the highest alkenes are found in the bio-oil of rice husks. Pyrolysis or thermal cracking is the process of breaking the alkanes by heating at high temperature in the absence of oxygen that produce alkanes and alkenes with the shorter carbon chains [45].

The main cracking reactions of one or more covalent carbon-carbon bonds in the hydrocarbon molecules are
Table 3 Chemical composition of bio-oil from rice husk pyrolysis according to the GC-MS analysis

\begin{tabular}{|c|c|c|}
\hline No. & Compound name & Mole fraction $(\%)$ \\
\hline 1 & Pentane, 3,3-dimethyl- & 4.20 \\
\hline 2 & 1-Hexene, 3,4-dimethyl & 11.06 \\
\hline 3 & Oxirane, 2-3thyl-2methyl- & 29.06 \\
\hline 4 & Hexane, 2-chloro- & 20.35 \\
\hline 5 & Phenol & 5.93 \\
\hline 6 & Phenol, 2-methoxy- & 2.37 \\
\hline 7 & Tridecane & 0.54 \\
\hline 8 & Tetradecane & 0.52 \\
\hline 9 & Dodecane, 2,6,10-trimethyl- & 0.98 \\
\hline 10 & 1-Nonadecene & 0.49 \\
\hline 11 & Pentadecane & 0.99 \\
\hline 12 & Dodecanoic acid, methyl ester & 1.54 \\
\hline 13 & Hexadecane & 1.23 \\
\hline 14 & Nonadecane, 9-methyl- & 0.96 \\
\hline 15 & Octadecane & 1.33 \\
\hline 16 & Pentadecane, 2,6,10,14-tetramethyl- & 3.54 \\
\hline 17 & Octadecane & 1.47 \\
\hline 18 & Nonadecane & 1.30 \\
\hline 19 & Hexadecanoic acid, methyl ester & 0.58 \\
\hline 20 & Eicosane & 1.16 \\
\hline 21 & Heptacosane & 1.61 \\
\hline 22 & Citronellol epoxide & 0.83 \\
\hline 23 & Eicosane & 0.64 \\
\hline 24 & $\begin{array}{c}\text { (E)-5-isopropyl-6,7-Epoxy-8-Hydroxy- } \\
\text { 8-Methylnon-2-one }\end{array}$ & 0.04 \\
\hline 25 & (Z)14-Tricosenyl formate & 0.48 \\
\hline 26 & $\begin{array}{l}\text { Cyclopentane,1-(2-decyldodecyl)-2,4- } \\
\text { dimethyl- }\end{array}$ & 0.19 \\
\hline 27 & HAHNFETT & 1.38 \\
\hline 28 & HAHNFETT & 3.53 \\
\hline 29 & Docosane & 0.92 \\
\hline 30 & Heptacosane & 0.78 \\
\hline
\end{tabular}




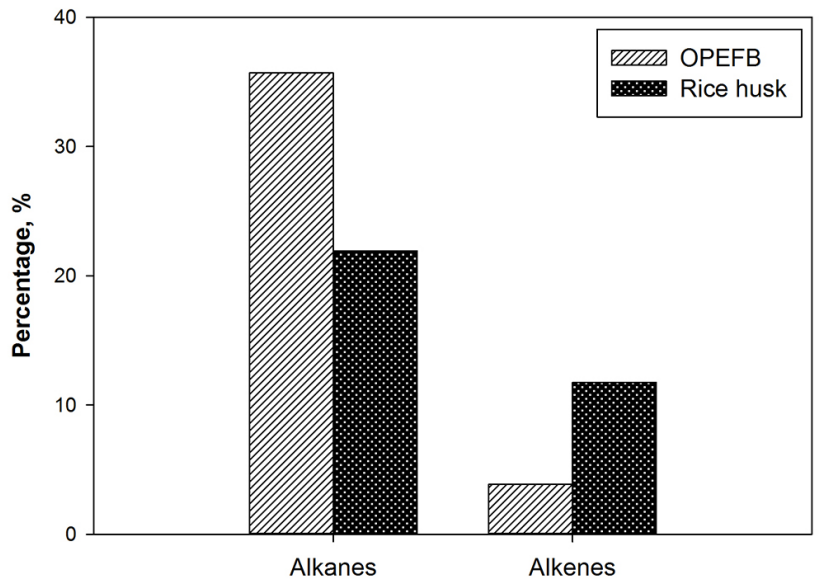

Fig. 8 Hydrocarbon distribution of bio-oil from OPEFB and rice husk

taken place by the mechanism of free radicals. As a result, a large number of small molecules formed. At the same time, a dehydrogenation reaction occurs by cracking the carbon-hydrogen bond. The cracking reaction of alkanes are shown in Eq. (5) and Eq. (6):

$$
\mathrm{C}_{\mathrm{n}} \mathrm{H}_{2 \mathrm{n}+2} \rightarrow \mathrm{C}_{\mathrm{m}} \mathrm{H}_{2 \mathrm{~m}+2}+\mathrm{C}_{\mathrm{q}} \mathrm{H}_{2 \mathrm{q}}
$$

Alkane alkane alkene

$$
\mathrm{C}_{\mathrm{n}} \mathrm{H}_{2 \mathrm{n}+2} \rightarrow \mathrm{C}_{\mathrm{n}} \mathrm{H}_{2 \mathrm{n}}+\mathrm{H}_{2}
$$

\section{Alkane alkene hydrogen}

Hence, both reactions produced alkanes and alkenes as the product of bio-oil. The uses are for combustion in diesel engines/turbines for power generation [46]. An essential parameter for diesel fuel is the viscosity because it affects the quality of fuel atomization to achieve proper air-fuel mixing and the formation of deposits in the engine - the distribution of molecular mass and alkene content influencing the value of viscosity. In the case of ignition delay, shallow alkene content in diesel fuel has the benefit of achieving the previous ignition. Low fuel alkene content inhibits the formation of molecules with high molecular mass, which induces previous ignition and benefits for diesel engine performance. The per cent area of alkenes on rice husks is higher than OPEFB, therefore the OPEFB is more preferred for bio-oil production by the pyrolysis process.

\subsection{Gas products characterization via gas chromatography mass spectrometry (GCMS)}

The gas products from the pyrolysis process of biomass are the result of thermal cracking reactions from organic compounds contained in biomass. Different composition of organic matter contained in biomass produce different chemical compositions of gas products. In general,
Table 4 Chemical compositions of gas products obtained from OPEFB and rice husk pyrolysis

\begin{tabular}{lcc}
\hline \multirow{2}{*}{ Chemical composition } & \multicolumn{2}{c}{ Percentage (\%) } \\
\cline { 2 - 3 } & OPEFB & rice husk \\
\hline Alanin Ethylamide & 95.79 & - \\
Trans-Beta-Ionon-5,6-Epoxide & - & 51.50 \\
2-Butene & 1.38 & 6.53 \\
2-Propanone & 1.30 & 6.60 \\
Furan & - & 15.72 \\
Acetic acid, hydrazide & 1.53 & 4.14 \\
2-Butanone & - & 3.92 \\
Benzene & - & 3.55 \\
Methyl Benzene & - & 8.06 \\
\hline
\end{tabular}

the pyrolysis process in biomass materials with a limited oxygen environment produce unsaturated hydrocarbon compounds (olefins). The results of chemical composition analysis in gas products carried out in this study are shown in Table 4. The chemical composition of the gas products produced by OPEFB and rice husks looks significantly different. The chemical composition of the gas produced from the pyrolysis of rice husks is having more variations than the OPEFB, due to differences in chemical composition in each feedstock.

Table 4 shows that the gas from pyrolysis of OPEFB dominate by alanine ethyl amide compounds (about $95 \%$ ), followed by hydrocarbon derivative compounds namely acetic acid hydrazide (1.53\%), butene (1.38\%), and propanone (1.30\%). Alanine ethyl amide compounds are volatile organic compounds (VOCs), which are quite flammable. These compounds are the result of decomposition of peptide compounds which are constituents of plant cells. Further decomposition of this compound is a hydrazide compound. The composition of the gas from the rice husk pyrolysis shows a different result, where epoxide compounds dominate the gas composition. Epoxide compounds are flammable, volatile organic compounds (VOCs), formed from the oxidation of olefins. The simplified mechanism of epoxide formation from rice husk pyrolysis is shown in Fig. 9. The results of this study indicate the potential for utilizing epoxide compounds produced by thermal cracking of rice husks, which reaches $52 \%$ of the total gas produced. Further studies need to be carried out to optimize the production of epoxide compounds from thermal cracking of rice husks.

The second major component of gas produced from rice husk pyrolysis is furan (15.72\%). Furan is a volatile organic compound (VOC) which is also flammable and is the result 


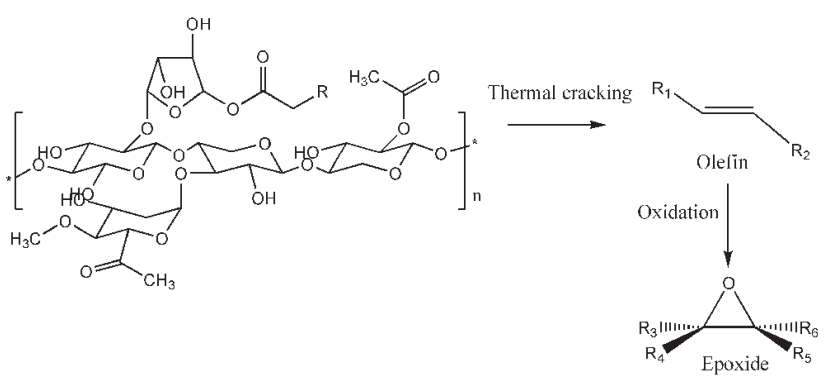

Fig. 9 Simplified mechanism of epoxide formation from biomass pyrolysis

of thermal decomposition of pentose sugar compounds [47]. Pentose sugar found in many plant cell walls. The next component is unsaturated hydrocarbon compounds such as butene and benzene, which produced through a thermal cracking process. From the results of this study, it revealed that the pyrolysis process of biomass, especially EFB and rice husk has the potential to produce gas that can be used as fuel. Also, some compounds have the potential to be used as an intermediate chemical product such as epoxide which used as one of the raw materials for epoxy adhesives.

Based on the chemical component identification listed in Table 4, the gasses are condensable gas. However, it obtained in the gas sampling point. It could be due to the condensing system couldn't accommodate the complete condensation process. It may also come from the inappropriate flow rate, the temperature of cooling water, effective heat transfer area, and gas residence time in the condenser. This phenomenon underlies the reason why the production of bio-oil in this study was far below from the bio-oil production reported in the previous study. In the previous study conducted by Balagurumurthy et al. [27], they used chilled water at $4{ }^{\circ} \mathrm{C}$ as cooling water in the condensing system, which maximized the bio-oil production. The results of the gas compound evaluation also reveal that the pyrolysis of biomass in the absence of air or steam is going to produced $\mathrm{CO}_{2}, \mathrm{CO}$, and $\mathrm{H}_{2}$ gasses in low concentration.

\subsection{Heating rate of pyrolysis process at constant power supply}

Biomass pyrolysis experiments conducted with constant power supply; however, it needs different time to reach a targeted temperature between rice husk and OPEFB. It indicates that biomass has an essential role in heat transfer. Fig. 10 shows the time duration for complete pyrolysis reaction at various temperatures using the same feed mass (450 g). The pyrolysis reaction considered complete if there is no more gas produced. Based on Fig. 10, the reaction time decreased along with the increase of reaction temperature. The higher temperature indicates more energy to initiate the reaction and kinetics energy to provide faster reaction. At the same pyrolysis temperature $(300,400,500$ and $600{ }^{\circ} \mathrm{C}$ ), rice husk gives longer time to complete the cracking process. OPEFB and rice husk required 115 and $120 \mathrm{~min}$ respectively, to complete the reaction at the temperature of $300{ }^{\circ} \mathrm{C}$. At the highest temperature of $600{ }^{\circ} \mathrm{C}$ OPEFB and rice husk required 66 and 74 min respectively, to complete the reaction. The complexity of the biomass chemical structure affected the different reaction time. Thus, rice husk needs a longer time to complete the reaction.

Fig. 11 shows that the heating rates (the rate of heating from an initial condition to targeted temperature) increase with the increasing of temperature at the constant

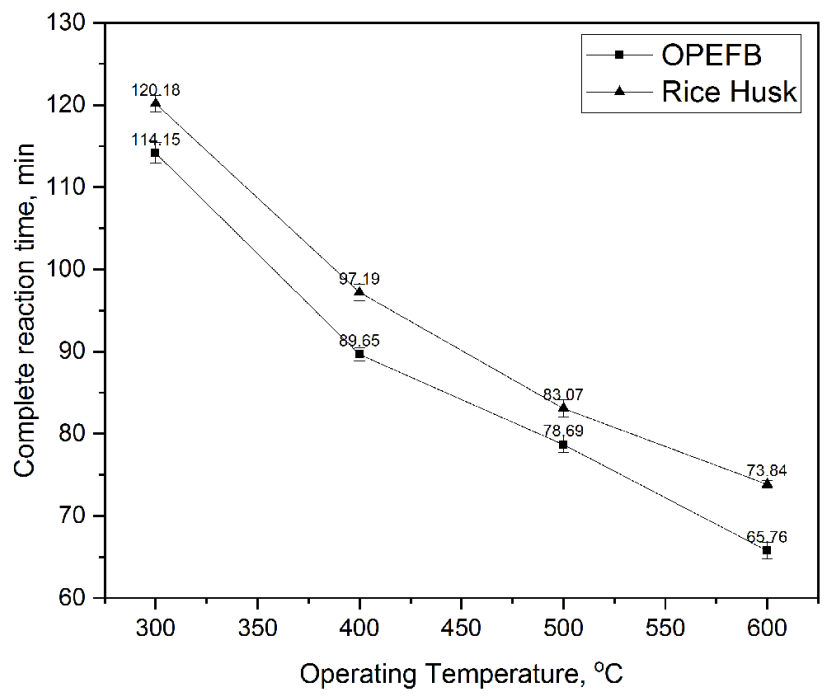

Fig. 10 Relationship between temperature with pyrolysis reaction time

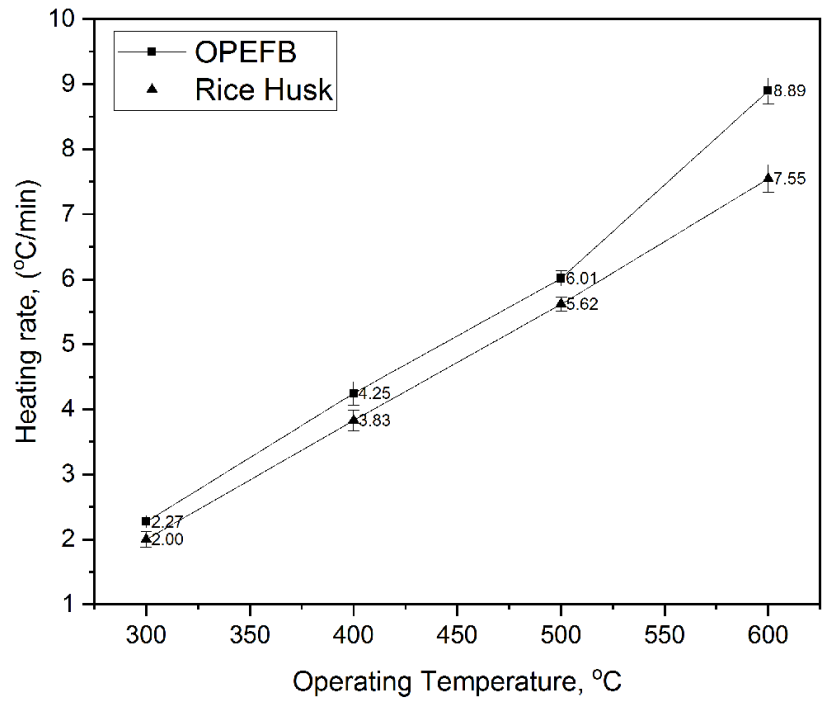

Fig. 11 Relationship between temperature with heating rates of biomass 
power supply. Pyrolysis with rice husk as biomass gives $2.25{ }^{\circ} \mathrm{C} / \mathrm{min}$ with $300{ }^{\circ} \mathrm{C}$ as targeted temperature and $7.70{ }^{\circ} \mathrm{C} / \mathrm{min}$ with $600{ }^{\circ} \mathrm{C}$ as targeted temperature. OPEFB gives $2.34{ }^{\circ} \mathrm{C} / \mathrm{min}$ with $300{ }^{\circ} \mathrm{C}$ as targeted temperature and $8.76^{\circ} \mathrm{C} / \mathrm{min}$ with $600^{\circ} \mathrm{C}$ as targeted temperature. The difference in the heating rate at the same power supply is influenced by material thermal conductivity. As reported by previous research, OPEFB had thermal conductivity of $0.069-0.2 \mathrm{~W} \cdot \mathrm{m}^{-1} \cdot \mathrm{K}^{-1}$ [48] while rice husk was found to be $0.01-0.15 \mathrm{~W} \cdot \mathrm{m}^{-1} \cdot \mathrm{K}^{-1}$ [49]. The higher thermal conductivity of the material gives higher heat transfer at the same temperature gradient.

Generally, maximum liquid yields could be obtained with higher heating rates to minimize secondary reaction [50]. Based on this study, OPEFB produced higher liquid yield (bio-oil) compared with rice husks. Besides the higher lignocellulosic content in OPEFB, it also has a higher thermal conductivity that leads to higher heating rate.

\subsection{Comparison of pyrolysis product distribution between OPEFB and rice husk}

The distribution of the pyrolysis products varies depending on the type of biomass used. As discussed in Section 3.7, OPEFB and rice husk pyrolysis show different product distribution and also product chemical compositions, it was attributed by the elemental composition of each biomass. Fig. 12 shows the comparison of overall product distribution given by OPEFB and rice husk pyrolysis.

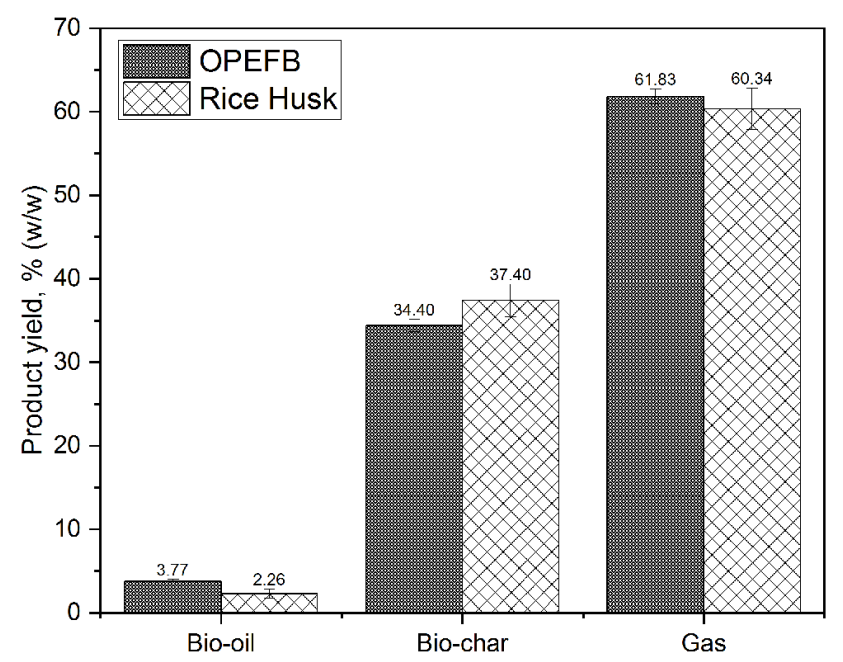

Fig. 12 Comparison of product yields between OPEFB and rice husks pyrolysis at $600^{\circ} \mathrm{C}$
Based on Fig. 12, OPEFB and rice husk shows a different yield of pyrolysis product at the same operating condition. The overall bio-oil and gas yields of OPEFB are higher than those of rice husk. OPEFB have greater bio-oil yield due to the higher lignocellulose content and higher thermal conductivity. Thermal degradation of cellulose produces the liquid fraction (bio-oil) consisted mainly of water, hydrocarbon, and oxygenated hydrocarbon. The higher char yield in the rice husks related to the ash content of the rice husk in the proximate analysis (Table 1). Moreover, the lignin on the rice husk is slightly higher than OPEFB, where thermal degradation of lignin gives higher yields of charcoal and tar [17]. Overall, OPEFB pyrolysis shows higher conversion than rice husk pyrolysis as well as more bio-oil and gas products.

\section{Conclusion}

The pyrolysis experiment of two different agricultural wastes shows that the pyrolysis product distributions were strongly influenced by operating condition (reactor temperature). Under the identical operating condition, the product distributions vary depending on the types of biomass. The highest bio-oil productions from OPEFB and rice husk pyrolysis were $4.3 \%(\mathrm{w} / \mathrm{w})$ and $2.6 \%(\mathrm{w} / \mathrm{w})$, respectively, achieved at a temperature condition of $500{ }^{\circ} \mathrm{C}$. The bio-energy potentials of OPEFB and rice husk were found to be $4010 \mathrm{kcal} / \mathrm{kg}$ and $3627 \mathrm{kcal} / \mathrm{kg}$, respectively. Thermal conductivity of biomass determined the heating rate of the reactor under the constant power supply. The chemical composition analysis revealed that the bio-oils were similar and mainly composed by hydrocarbons and oxygenated hydrocarbons. OPEFB pyrolysis produced more hydrocarbon portion in bio-oil while rice husk produced more oxygenated hydrocarbons in the bio-oil product. The gas products analysis also indicates that the produced gases are flammable and has potential as a fuel.

\section{Acknowledgement}

The authors would like to acknowledge LPPM University of Diponegoro for the research funding under research grant scheme RPI (International Publication Research), which makes this research viable and effective. The author would also show gratitude towards Waste treatment laboratory of the Chemical Engineering Department, Diponegoro University, for the supporting facilities. 


\section{References}

[1] IEA "World Energy Outlook 2018", IEA, Paris, France, 2018. https://doi.org/10.1787/weo-2018-en

[2] Mohr, S. H., Wang, J., Ellem, G., Ward, J., Giurco, D. "Projection of world fossil fuels by country", Fuel, 141, pp. 120-135, 2015. https://doi.org/10.1016/j.fuel.2014.10.030

[3] Picchi, G., Lombardini, C., Pari, L., Spinelli, R. "Physical and chemical characteristics of renewable fuel obtained from pruning residues", Journal of Cleaner Production, 171, pp. 457-463, 2018. https://doi.org/10.1016/j.jclepro.2017.10.025

[4] Bhattacharjee, N., Biswas, A. B. "Pyrolysis of orange bagasse: Comparative study and parametric influence on the product yield and their characterization", Journal of Environmental and Chemical Engineering, 7(1), p. 102903, 2019.

https://doi.org/10.1016/j.jece.2019.102903

[5] Katinas, V., Marčiukaitis, M., Perednis, E., Dzenajavičienė, E. F. "Analysis of biodegradable waste use for energy generation in Lithuania", Renewable Sustainable Energy Reviews, 101, pp. 559-567, 2019.

https://doi.org/10.1016/j.rser.2018.11.022

[6] Yustinah, Y., Hidayat, N., Alamsyah, R., Roslan, A. M., Hermansyah, H., Gozan, M. "Production of polyhydroxybutyrate from oil palm empty fruit bunch (OPEFB) hydrolysates by Bacillus cereus suaeda B-001", Biocatalysis and Agricultural Biotechnology, 18, p. 101019, 2019.

https://doi.org/10.1016/j.bcab.2019.01.057

[7] Yoo, H. M., Park, S. W., Seo, Y. C., Kim, K. H. "Applicability assessment of empty fruit bunches from palm oil mills for use as bio-solid refuse fuels", Journal of Environmental Management, 234, pp. 1-7, 2019.

https://doi.org/10.1016/j.jenvman.2018.11.035

[8] Lutfi, M., Yamin, M., Rahman, M., Popang, E. G. "A comparative analysis of the quality of concrete blocks produced from coconut fibre, oil palm empty fruit bunch, and rice husk as filler material", MATEC Web Conf., 195, p. 01019, 2018.

https://doi.org/10.1051/matecconf/201819501019

[9] Christian, L., Juwitasary, H., Putra, E. P., Fifilia, F., Chandra, Y. U. "Development Model Availability of Rice in Indonesia Using System Dynamics Approach", In: International Conference on Information Management and Technology (ICIMTech), Jakarta, Indonesia, 2018, pp. 1-9. https://doi.org/10.1109/ICIMTech.2018.8528173

[10] Hakeem, K. R., Jawaid, M., Alothman, O. Y. "Agricultural Biomass Based Potential Material", Springer, Cham, Switzerland, 2015. https://doi.org/10.1007/978-3-319-13847-3

[11] Park, C. S., Roy, P. S., Kim, S. H. "Current Developments in Thermochemical Conversion of Biomass to Fuels and Chemicals In Gasification for Low-grade Feedstock", In: Yun, Y. (ed.) Gasification for Low-grade Feedstock, IntechOpen, London, UK, 2018, pp. 19-41. https://doi.org/10.5772/intechopen.71464

[12] Lajili, M., Guizani, C., Escudero Sanz, F. J., Jeguirim, M. "Fast pyrolysis and steam gasification of pellets prepared from olive oil mill residues", Energy, 150, pp. 61-68, 2018. https://doi.org/10.1016/j.energy.2018.02.135

[13] Al Arni, S. "Comparison of slow and fast pyrolysis for converting biomass into fuel", Renewable Energy, 124, pp. 197-201, 2018. https://doi.org/10.1016/j.renene.2017.04.060
[14] Hameed, S., Sharma, A., Pareek, V., Wu, H., Yu, Y. "A review on biomass pyrolysis models: Kinetic, network and mechanistic models", Biomass and Bioenergy, 123, pp. 104-122, 2019. https://doi.org/10.1016/j.biombioe.2019.02.008

[15] Tahir, M. H., Çakman, G., Goldfarb, J. L., Topcu, Y., Naqvi, S. R., Ceylan, S. "Demonstrating the suitability of canola residue biomass to biofuel conversion via pyrolysis through reaction kinetics, thermodynamics and evolved gas analyses", Bioresource Technology, 279, pp. 67-73, 2019. https://doi.org/10.1016/j.biortech.2019.01.106

[16] Ji-lu, Z. "Bio-oil from fast pyrolysis of rice husk: Yields and related properties and improvement of the pyrolysis system", Journal of Analytical and Applied Pyrolysis, 80(1), pp. 30-35, 2007. https://doi.org/10.1016/j.jaap.2006.12.030

[17] Heo, H. S., Park, H. J., Park, Y. K., Ryu, C., Suh, D. J., Suh, Y. W., Yim, J. H., Kim, S. S. "Bio-oil production from fast pyrolysis of waste furniture sawdust in a fluidized bed", Bioresource Technology, 101(1), pp. S91-S96, 2001. https://doi.org/10.1016/j.biortech.2009.06.003

[18] Park, H. J., Dong, J. I., Jeon, J. K., Park, Y. K., Yoo, K. S., Kim, S. S., Kim, J., Kim. S. "Effects of the operating parameters on the production of bio-oil in the fast pyrolysis of Japanese larch", Chemical Engineering Journal, 143(1-3), pp. 124-132, 2008. https://doi.org/10.1016/j.cej.2007.12.031

[19] Sulaiman, F., Abdullah, N. "Optimum conditions for maximising pyrolysis liquids of oil palm empty fruit bunches", Energy, 36(5), pp. 2352-2359, 2011. https://doi.org/10.1016/j.energy.2010.12.067

[20] Guedes, R. E., Luna, A. S., Torres, A. R. "Operating parameters for bio-oil production in biomass pyrolysis: A review", Journal of Analytical and Applied Pyrolysis, 129, pp. 134-149, 2018. https://doi.org/10.1016/j.jaap.2017.11.019

[21] ASTM Iternational, 2016, ASTM D5373-16, Standard Test Methods for Determination of Carbon, Hydrogen and Nitrogen in Analysis Samples of Coal and Carbon in Analysis Samples of Coal and Coke, West Conshohocken, PA. https://doi.org/10.1520/D5373-16

[22] ASTM International, 2017, ASTM D3173 / D3173M-17a, Standard Test Method for Moisture in the Analysis Sample of Coal and Coke, West Conshohocken, PA. https://doi.org/10.1520/D3173_D3173M-17A

[23] ASTM International, 2018, ASTM D3174-12(2018), Standard Test Method for Ash in the Analysis Sample of Coal and Coke from Coal, West Conshohocken, PA. https://doi.org/10.1520/D3174-12R18

[24] International Organization for Standardization, 2010, ISO 562:2010, Hard coal and coke -- Determination of volatile matter. [online] Available at: https:/www.iso.org/standard/55943.html [Accessed: 05 January 2019]

[25] ASTM International, 2013, ASTM D3172-13, Standard Practice for Proximate Analysis of Coal and Coke, West Conshohocken, PA. https://doi.org/10.1520/D3172-13

[26] ASTM International, 2013, ASTM D5865-13, Standard Test Method for Gross Calorific Value of Coal and Coke, West Conshohocken, PA.

https://doi.org/10.1520/D5865-13 
[27] Balagurumurthy, B., Srivastava, V., Vinit, V., Kumar, J., Biswas, B., Singh,R., Gupta, P., Shiva Kumar, K. L. N., Singh, R., Bhaskar, T. "Value addition to rice straw through pyrolysis in hydrogen and nitrogen environments", Bioresource Technology, 188, pp. 273-279, 2015.

https://doi.org/10.1016/j.biortech.2015.01.027

[28] Biswas, B., Pandey, N., Bisht, Y., Singh, R., Kumar, J., Bhaskar, T. "Pyrolysis of agricultural biomass residues: Comparative study of corn cob, wheat straw, rice straw and rice husk", Bioresource Technology, 237, pp. 57-63, 2017. https://doi.org/10.1016/j.biortech.2017.02.046

[29] Azat, S., Korobeinyk, A. V., Moustakas, K., Inglezakis, V. J. "Sustainable production of pure silica from rice husk waste in Kazakhstan", Journal of Cleaner Production, 217, pp. 352-359, 2019. https://doi.org/10.1016/j.jclepro.2019.01.142

[30] Andreola, F., Lancellotti, I., Manfredini, T., Bondioli, F., Barbieri, L. "Rice Husk Ash (RHA) Recycling in Brick Manufacture: Effects on Physical and Microstructural Properties", Waste and Biomass Valorization, 9(12), pp. 2529-2539, 2018. https://doi.org/10.1007/s12649-018-0343-5

[31] Loy, A. C. M., Yusup, S., Lam, M. K., Chin, B. L. F., Shahbaz, M., Yamamoto, A., Acda, M. N. "The effect of industrial waste coal bottom ash as catalyst in catalytic pyrolysis of rice husk for syngas production", Energy Conversion and Management, 165, pp. 541-554, 2018.

https://doi.org/10.1016/j.enconman.2018.03.063

[32] Sudiyani, Y., Styarini, D., Triwahyuni, E., Sudiyarmanto, S., Sembiring, K. C., Aristiawan, Y., Abimanyu, H., Han, M. H. "Utilization of Biomass Waste Empty Fruit Bunch Fiber of Palm Oil for Bioethanol Production Using Pilot-Scale Uni", Energy Procedia, 32, pp. 31-38, 2013.

https://doi.org/10.1016/j.egypro.2013.05.005

[33] Demirbaş, A. "Mechanisms of liquefaction and pyrolysis reaction of biomass", Energy Conversion and Management, 41(6), pp. 633646, 2000. https://doi.org/10.1016/S0196-8904(99)00130-2

[34] Kim, S. W., Koo, B. S., Ryu, J. W., Lee, J. S., Kim, C. J., Lee, D. H., Kim, G. R., Choi, S. "Bio-oil from the pyrolysis of palm and Jatropha wastes in a fluidized Bed", Fuel Processing Technology, 108, pp. 118-124, 2013. https://doi.org/10.1016/j.fuproc.2012.05.002

[35] Siramard, S., Xu, G., Zhan, J. H., Han, Z., Xu, S., Mašek, O. "Secondary cracking of volatile and its avoidance in infrared-heating pyrolysis reactor", Carbon Resources Conversion, 1(3), pp. 202-208, 2018.

https://doi.org/10.1016/j.crcon.2018.09.001

[36] Chen, W., Chen, Y., Yang, H., Li, K., Chen, X., Chen, H. "Investigation on biomass nitrogen-enriched pyrolysis: Influence of temperature", Bioresource Technology, 249, pp. 247-253, 2018. https://doi.org/10.1016/j.biortech.2017.10.022

[37] Yan, Q., Toghiani, H., Yu, F., Cai, Z., Zhang, J. "Effects of pyrolysis conditions on yield of bio-chars from pine chips", Forest Products Journal, 61(5), pp. 367-371, 2011. [online] Available at: https://www. fs.usda.gov/treesearch/pubs/40273 [Accessed: 05 January 2019]

[38] Rahman, A. A., Sulaiman, F., Abdullah, N. "Effect of Temperature on Pyrolysis Product of Empty Fruit Bunches", AIP Conferece Proceedings, 1657(1), p. 040011, 2015. https://doi.org/10.1063/1.4915172
[39] Wang, Z., Li, J., Barford, J. P., Hellgradt, K., McKay, G. "A comparison of chemical treatment methods for the preparation of rice husk cellulosic fibers", International Journal of Environmental \& Agriculture Research, 2(1), pp. 67-77, 2016. [online] Available at: https://ijoear.com/Paper-January-2016/IJOEAR-JAN-2016-11.pdf [Accessed: 05 January 2019]

[40] Palamae, S., Dechatiwongse, P., Choorit, W., Chisti, Y., Prasertsan, P. "Cellulose and hemicellulose recovery from oil palm empty fruit bunch (EFB) fibers and production of sugars from the fibers", Carbohydrate Polymers, 155, pp. 491-497, 2017. https://doi.org/10.1016/j.carbpol.2016.09.004

[41] Demirbas, A. "Effects of temperature and particle size on bio-char yield from pyrolysis of agricultural residues", Journal of Analytical and Applied Pyrolysis, 72(2), pp. 243-248, 2004.

https://doi.org/10.1016/j.jaap.2004.07.003

[42] Sukiran, M. A., Chin, C. M., Bakar, N. K. A. "Bio-oils from Pyrolysis of Oil Palm Empty Fruit Bunches", American Journal of Applied Sciences, 6(5), pp. 869-875, 2009. https://doi.org/10.3844/ajassp.2009.869.875

[43] Ahmad, F. B., Zhang, Z., Doherty, W. O. S., O’Hara, I. M. "Evaluation of oil production from oil palm empty fruit bunch by oleaginous micro-organisms", Biofuels, Bioproducts and Biorefining, 10(4), pp. 378-392, 2016.

https://doi.org/10.1002/bbb.1645

[44] Macfarlane, A. L., Mai, M., Kadla, J. F. "20-Bio-based chemicals from biorefining: lignin conversion and utilisation", In: Waldron, K. (ed.) Advances in Biorefineries, Woodhead Publishing, Cambridge, UK, 2014, pp. 659-692. https://doi.org/10.1533/9780857097385.2.659

[45] Montoya, J. I., Chejne-Janna, F., Garcia-Pérez, M. "Fast Pyrolysis of Biomass: A Review of Relevant Aspects. Part I: Parametric Study", DYNA, 82(192), pp. 239-248, 2015. https://doi.org/10.15446/dyna.v82n192.44701

[46] Sembiring, K. C., Rinaldi, N., Simanungkalit, S. P. "Bio-oil from Fast Pyrolysis of Empty Fruit Bunch at Various Temperature", Energy Procedia, 65, pp. 162-169, 2015. https://doi.org/10.1016/j.egypro.2015.01.052

[47] Nie, S., Huang, J., Hu, J., Zhang, Y., Wang, S., Li, C., Marcone, M., Xie, M. "Effect of $\mathrm{pH}$, temperature and heating time on the formation of furan in sugar-glycine model systems", Food Science and Human Wellness, 2(2), pp. 87-92, 2013. https://doi.org/10.1016/j.fshw.2013.05.001

[48] Hassan, S., Tesfamichael, A., Mohd Nor, M. F. "Comparison Study of Thermal Insulation Characteristics from Oil Palm Fibre", MATEC Web of Conferences, 13, p. 02016, 2014. https://doi.org/10.1051/matecconf/20141302016

[49] Mishra, P., Chakraverty, A., Banerjee, H. D. "Studies on physical and thermal properties of rice husk related to its industrial application", Journal of Materials Science, 21(6), pp. 2129-2132, 1986. https://doi.org/10.1007/BF00547958

[50] Tsai, W. T., Lee, M. K., Chang, Y. M. "Fast pyrolyis of rice husk: Product yields and compositions", Bioresource Technology, 98(1), pp. 22-28, 2007. https://doi.org/10.1016/j.biortech.2005.12.005 